\title{
Piezo-electric surgery use for the management of patients with onj drug-induced: our experience
}

\author{
M G Cristofaro ${ }^{*}$, A Giudice, W Colangeli, M Amantea, M Giudice \\ From de Senectute: Age and Health Forum \\ Catanzaro, Italy. 5-7 December 2009
}

\section{Background}

Piezo-electric surgery is a procedure used recently in Oral-Maxillo-Facial Surgery [1]. The basic mechanisms are ultrasounds, that working in a frequency range between 25 and $30 \mathrm{Khz}$, determining very low oscillations on the tip of the handpiece, with effectiveness in cutting hard tissue but absolutely atraumatic on the soft tissue [2], with bio-stimulating effects. Piezo-electric cut takes place thanks to a modulate ultrasonic micro-vibration of 60-200 micro-meters of wideness, that it is able to cut all the mineralized tissues with the utmost respect to the soft tissue, impossible to damage even in an accidental contact. The bio-stimulation induces neo-angiogenesis, proliferation of epithelial tissue, increase of osteoblastic activity. In our Department of Maxillo-Facial Surgery a clinical study is ongoing whose aim is to demonstrate Piezo-Surgery validity as an adjuvant treatment for patient management in stage I $(a, b)$, II $(a, b)$ and stage IIIa (following the AAOMFS classification).

\section{Materials and methods}

From January 2003 to September 2009, 18 patients were treated with ONJ, 11 male and 7 female, range of age between 55 and 75.16 of them have been cured with Zolendronic acid for cancer and 2 with Alendronic acid for osteoporosis. All the patients' clinical conditions were classified following the AAOMFS.

Piezo-Surgery treatment has been carried out in more sessions and always under our protocol (Table 1). Small sequestrectomies and superficial debridements were performed with Piezo-Surgery in cutting mode and medium power; for the initial steps atraumatic rabbet or hooked cutting tips are necessary, that enable the removal and contemporary the bone remodeling. In a second phase atraumatic shaped ball tips were used for

\section{Department of Maxillofacial Surgery, Magna Graecia University, Catanzaro,} Italy the soft tissue bio-stimulation with the Piezo-Surgery in standard mode. The entire surgical procedure needs abundant irrigation with sterile saline and broad-spectrum antibiotics.

\section{Results}

The results are indicated in Table.2: in 4 patients the results aren't satisfactory; 10 patients are stationary; 3 patients improved (Figure 1); 1 patient has completely recovered (Figure 2).

\section{Conclusions}

PiezoSurgery carried out a clinical improvement of patients for its biostimulation effects.

Published: 19 May 2010

Table 1 Anti-bacterial therapy

Amoxillina $1 \mathrm{gr} \mathrm{cp}: 2 \mathrm{cp} /$ die per $10 \mathrm{gg}$.

Clorexidina coll. 0,2\%: rinses three times/day for $10 \mathrm{gg}$.

Nistatina 2-3 mis.die per $10 \mathrm{gg}$.

Metronidazolo cp $250 \mathrm{mg} 2 \mathrm{cp}$ per 4 die in $1 \mathrm{gg}$

Each cycle of therapy between the other has ten days of drug holiday

Table 2

\begin{tabular}{|c|c|c|}
\hline Patients Number & Initial Stage & Final stage \\
\hline *6 & *lia & * $\|$ la \\
\hline *4 & *Illa & *\|lla \\
\hline$\# 2$ & \#lla & $\# l l b$ \\
\hline \#2 & \#llb & \#llla \\
\hline$\wedge 1$ & $\wedge \| \mathrm{a}$ & $\wedge l b$ \\
\hline$\wedge 2$ & $\wedge \| l l a$ & $\wedge \| \mathrm{b}$ \\
\hline+1 & $+l l a$ & +0 \\
\hline
\end{tabular}

* n. 10 clinical condition

\# n. 4 worsted

$\wedge$ n. 3 improved

$+n$. 1 clinically free from Disease 


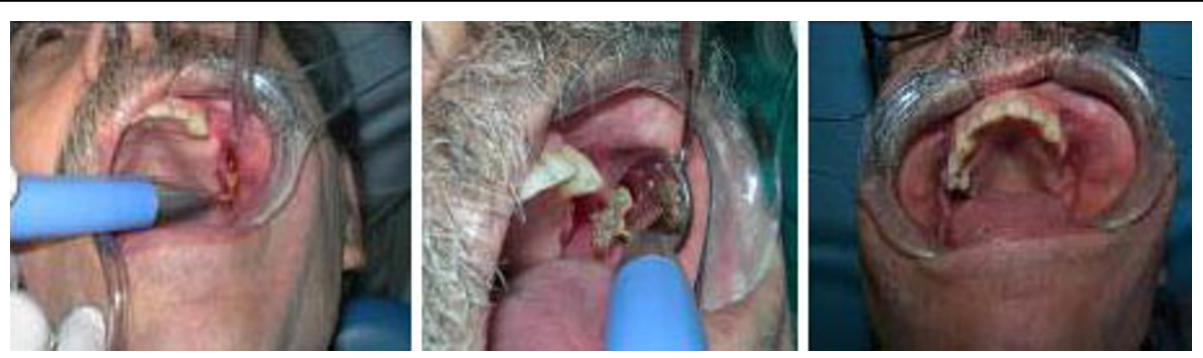

Figure 1 Stage lla to $\mathrm{lb}$, the clinical condition are improved after ten months of treatment
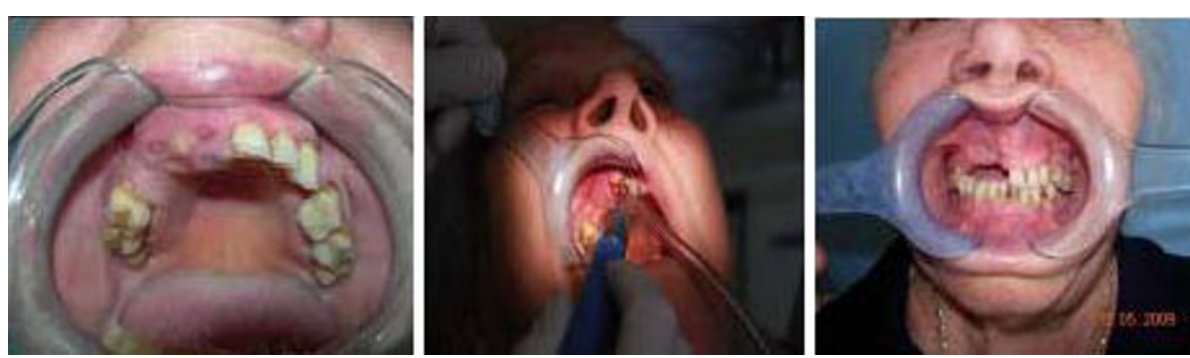

Figure 2 stage lla to 0, clinical free from desease after ten months of treatment

\section{References}

1. Eggers G, Klein J, Blank J, Hassfeld S: Piezosurgery: an ultrasound device for cutting bone and its use and limitation in maxillosurgery. British Journal of Oral and Maxillofacial Surgery 2004, 42(z):451-453.

2. Beziat JL, Bera JC, Lavandier B, Gleizal A: Ultrasonic osteotomy as a new technique in craniomaxillofacialsurgery. Int. J. Oral Maxillofac.Surg. 2007, 36:493-500

doi:10.1186/1471-2318-10-S1-A55

Cite this article as: Cristofaro et al:: Piezo-electric surgery use for the management of patients with onj drug-induced: our experience. $B M C$ Geriatrics 2010 10(Suppl 1):A55.

\section{Submit your next manuscript to BioMed Central} and take full advantage of:

- Convenient online submission

- Thorough peer review

- No space constraints or color figure charges

- Immediate publication on acceptance

- Inclusion in PubMed, CAS, Scopus and Google Scholar

- Research which is freely available for redistribution 